\title{
The Research of Self-Management Team and Superior- Direction Team in Team Learning Influential Factors
}

\author{
Zhang wei \\ Geography Department, Dezhou University, Dezhou, Shandong 253023, China
}

DOI: $\quad 10.6007 /$ IJARBSS/v3-i8/139 URL: http://dx.doi.org/10.6007/IJARBSS/v3-i8/139

\begin{abstract}
Team learning is a cure for bureaucracy; it facilitates team innovation and team performance. But team learning occurs only when necessary conditions were met. This research focused on differences of team learning influential factors between self-management team and superiordirection team. Four variables were chosen as predictors of team learning though literature review and pilot interview. The 4 variables are team motivation, team trust, team conflict and team leadership. Selected 54 self management teams and 23 superior-direction teams as participants, each member of all teams finished questionnaires which measure 4 predictor variables and dependent variable (team learning). Results show that in both the two type of teams, team motivation, team trust, team leadership are positive predictor of team learning, team conflict have negative correlation with team learning. Normative team motivation, team leadership (including feasance and democracy) positively predict team learning significantly in self-management team, whereas team leader's feasance is the only significant predictor which positively predict team learning in superior-direction team.
\end{abstract}

Keywords: Team Learning, Self-Management Team, Superior-Direction Team

\section{Introduction}

Team learning is defined here as a process of effectively using information to guide the team to achieve a sustainable adaptation to the changes of the environment (Edmondson A. C.,1996). When task became more and more complicated and time pressured, more likely that it is the team other than the individual who is going to be assigned the task in the organization. Team learning is regarded as a cure for bureaucray. The main characteristic of bureaucracy is segmentation (Kanter, 1983), that is to say, bureaucracy make distinction between "doing" and "thinking". Through team learning, "doing" and "thinking" will be combined together by information sharing (Zenon Chaczko, Jenny Quang, Bruce Moulton, 2010). Empirical researches have convincingly demonstrated that team learning facilitate team performance and team creativity (Hoever, I. J., et al., 2012). Chan et al. (2003) examined team learning in an Australian hospital and found there is positive correlation between team learning and team performance (Chan C. C., 2003). Xiao (2004) investigated teams in an automobile factory by field experiment and made a conclusion that team leaning promote team performance (Xiao Yuchun, 2003). Gajendran and Joshi (2012) surveyed 40 globally distributed team, they found that team 
communication enhance team innovation. However et al. (2012) found team information elaboration foster team creativity (Cajendran R. S., et al., 2012). However, team learning occurs only when necessary conditions were met. Cannon and Edmondson (2000) found that team learning-oriented beliefs promoted group performance and that effective coaching, clear direction, and a supportive work context were antecedents of group learning (Cannon M. A., Edmondson A., 2000). Argote et. al. (1995) reported that effects of turnover and task complexity influence team learning. There are so many different researches on team learning; controversies still exist about which variables are influential factors on team learning (Argote $L$., et al, 1995). Teams in organizations can be classified into two categories: self-management team and superiordirection team. Self-management teams are established by team members themselves, and are autonomous in most of team affaires. Superior-direction teams are formed by higher-rank officials and directed by superior in some magnitude issuses. Most of scholars didn't consider team type when they disscuss influential factors of team learning. This article focuses on differences of influential factors between self-management team and superiordirection team.

\section{Pilot Interview}

A lot of variables were mentioned in previous literature as influential factor of team learning (Wang Xiuli, Liu Dianzhi, Wu Tiejun, 2011). So, it is difficult to choose independent variables in this study. Pilot interview must be done before qualitative research start. Interview questions were designed in advance. It consisted of 5 interrogative sentences, such as "which factors/persons promoted/hindered team learning in your team activity", "how did these factors /persons promote/hinder team learning in your team?" Twelve members in 10 selfmanagement teams and 20 menbers in 13 superior-direction teams were interviewed respectively in separated conference room.

Dialogues of the interview were recorded with interviewee's consent, and they were transformed into Microsoft Word texts. Two well-trained post-graduate students coded the interview text respectively through the software Nvivo 7.0. If there was disagreement between them, they discussed over and over again until agreement was made.

Results of pilot interview indicate that there are 4 significant influential variables of team learning: (a) team motivation, team members had strongly willing to cooperation for the same goal, they always cherish their team-membership and their friendship with other team-mates; (b) team trust, team members felt psychological safety in team, team members believed that they are accepted by others in team no matter how naïve they look like; (c) team conflict, arguments and quarrels occurred among team members; (d) team leadership, how team leaders exert their power to integrate different opinions and to correct unconstructive behaviors.

\section{Methods}

\subsection{Hypotheses Development}

According to results of pilot interview and previous literature, 3 hypotheses were developed. 
Hypothesis 1, Team motivation, team trust, team leadership are positive predictor of team learning Team motivation is the collective system by which team members coordinate the direction, intensity, and persistence of their efforts (Chen, Kanfer, 2006). Weaver et al. (1997) differentiated task work motivation and team work motivation (Weaver J.L., et al., 1997). They argued that team performance is enhanced when these motivations are congruent not only with one another but also with the goal of the organization. Stewart et al (2011) believed that normative control and rational control are two main motivational state of teams. Normative control is a kind of interpersonal influence among team members; they feel influenced by their team mates through the pull of social inclusion and internalization. Rational control is utilitarian state that occurs when team members perceived their rewards as being dependent on the input and decisions of their teammates (Stewart G. L., Barrick M.R., 2011). We found both normative motivation and rational motivation in pilot interview, the former presented as the willing to establish harmony relationship with teammate, the later manifested as the willing to get higher performance and develop professional skills and abilities.

Team trust (psychological safe) is a shared belief that the team is safe for interpersonal risk taking (Edmondson A.C., 1999). Team trust strongly impacts team learning. Some scholars found that team trust and team efficacy mediated the relationship between the structural variable and team learning. Sense of psychological safe (team trust) is a key characteristic of successful team. Without team trust, members were less likely to take risk and to change (Edmondson A. C., 2002; Wu Tiejun, Liu Dianzhi, Bi Xin, 2010).

Both self-management team and superior-direction team are empowered in various levels in an organization. If team leader can not use appropriate way to lead the team to make full use of power to enhance performance such as nonfeasance or despotism, the team will lose its creativity and fall into powerless.

Hypothesis 2, Team conflict is the negative predictor of team learning

Team conflicts could be described as the disagreement of benefit, goal, or expectation among team members. Team conflicts are likely to bring both positive and negative outcomes. Amason \& Sapienza (1997) classified conflicts into 3 categories: Relationship Conflict, Task Conflict and Process Conflict.

Jehn showed that there was a +0.44 correlation between task conflict and team performance (Jehn K.A., 1994) and a -0.45 correlation between relationship conflict and performance (Jehn K.A., 1995). Team members are depressed by process conflict and their performance decline (Jehn K.A., Northcraft G.B., Neale M.A., 1999). Empirical evidences imply that relation conflict and process conflict do harm to team performance, but task conflict is helpful. Unfortunately, subsequent research failed to support this point (De Dreu CKW., Weingart L.R., 2003). A recent meta-analysis based upon 26 effect sizes, found the $95 \%$ confidence interval for the relationship between task conflict and performance to be -0.13 to -0.26 , making Jehn's result an extreme outlier.

Indeed, this same meta-analysis estimated the correlation between task and relationship conflict is over 0.50 . This seems to imply that conflict is unhelpful to performance, no matter what kind of conflict it is. Ilgen et. al. (2005) demonstrated that instead of task conflict, team require (a) rich, unemotional debate in a context based upon trust, (b) a context where team members feel free to express themselves and change their views, and (c) the ability to resist 
pressure to compromise quickly or to reach a premature consensus (Ilgen D.R, Hollenbeck J.R, Johnson M., Jundt D., 2005).

Although people dislike team conflict, it still occurs in team activities. Whether it is constructive or ruinous is dependent on how you manage it, not on how it occurs. Good strategies of conflict management can promote team bonding and team ability to solve problem. Dual-concern model of conflict management suggests that communication is a positive strategy to be employed; it combines the individual goals together to make a common team aim and also to release the hostility among team members.

Hypothesis 3, significant pridictors of team learning in two type of team exist difference

The organizational control is different for different types of team: self-management teams have more decision-making power, and superior-direction teams were slight tighter controlled by organization than self-management teams. So, four predict variables of two types of team may have different contribution on team learning.

\subsection{Instruments}

In this research, 5 questionnaires are used as instruments.

Team learning questionnaire: developed by Edmondson (1999) and consists 7 items. Edmondson defined 5 typical team learning behavior: (a) feed back seeking, (b) help seeking, (c) discussing error, (e) experimenting, (f) reflecting on experiences. But, there are only 7 items in the questionnaire. We can't imagine that team learning consisting of 5 typical behaviors are fully represented by 7 item questionnaire. So, 4 new items were added to the questionnaire according to interview material in order to improve reliability and validity.

The 4 new items are listed below. (1) Team members try to break up stereotype and develop new strategies and new methods. (2) Team members stand stranded without any exploration when they meet tough task. (3) Team members often read a lot in order to get the team goal. (4) Most of team mates are willing to share information and knowledge with others.

The Cronbach ? index of the questionnaire is 0.82 .

Team motivation questionnaire: developed by the authors, and consists 12 items. It composes of two dimensions: normative motivation and rational motivation. Satisfied structure validity of this questionnaire was proved by confirmed factor analysis (?2/df=4.361, CFI=0.825, NFI=0.794, RMSEA=0.108).

The items of team motivation questionnaire listed as follow. Items 1-6 belong to normative motivation dimension, items 7-12 belong to rational motivation dimension. (1) Making some friends through team activities is my favorite benefits. (2) I will be seriously anxious when disagreement appeared in my team. (3) Team success relies on good inter-personal relationship among team mates. (4) I seek for friendship in my team. (5) I establish deeply personal relationship with my team mate beyond team tasks. (6) Team cohesion sometimes is more important than team goals. (7) I love my team because I want to attain the goal of teams. (8) I feel so good when team performance is splendid. (9) I want to develop my skill and ability though team activities. (10) I am so upset when team task failed. (11) My team is a highly coordinated community because we shared same value and goal. (12) The most important things for a team are achieving team goals through teamwork.

Its Cronbach's ais 0.69. 
Team trust questionnaire: developed by Edmondson (1996) and it consists 8 items, Cronbach's ais 0.60 .

Team conflict questionnaire: developed by Jehn \& Mannix(2001), and is consisted of 8 items. Cronbach's ais 0.88 .

Team leadership questionnaire is developed by the authors, and it is consisted of 9 items. It composes of two dimensions: feasance and democracy. Excellent structure validity of the questionnaire was proved by confirmed factor analysis $(\mathrm{X} 2 / \mathrm{df}=2.164, \mathrm{CFI}=0.925, \mathrm{NFI}=0.876$, RMSEA=0.063) .

The items of team leadership questionnaire are listed below. Items 1-4 belong to democracy dimension, item5-9 belong to feasance dimension.(1) Only minority of my teams participate in decision-making about important team issues. (2) All member of my team take part in decisionmaking about important team events. (3) Team leader is the only decision-maker in my team. (4) Team leader consult relevant issues with his/her followers before decision-making. (5) Team leader strive for more resources from organization. (6) Team leader set attainable goals for teams when the followers have obscure vision about team's future. (7) Team leader help the followers to clarify team goal. (8) Team leader help the followers to grasp necessary skills. (9) Team leader gain prestige from the followers because of splendid leadership.

The Cronbach's sis 0.74 .

\subsection{Participants}

Some scholars who were interested in team learning used artificial teams as participants. Artificial teams are built by researchers for the sake of investigation. Although sampling difficulties have been reduced using artificial teams, ecological validity decreases at the same time. Real teams of college students were selected as subjects in this research. In this study, 457 individuals have been recruited from 77 teams as participants. In all participants, 164 individual are from 23 superior-direction teams; 293 individual belong to 54 self-management teams.(table 1) All subjects were invited to separate offices to finish questionnaires. Six senior students helped participants to understand items and collected filled questionnaires back after completion.

\begin{tabular}{|l|l|l|}
\hline Team type & Team number & Individual number \\
\hline Self management team & 54 & 293 \\
\hline Superior direction team & 23 & 164 \\
\hline total & 77 & 457 \\
\hline
\end{tabular}

Table 1. Overview of the Participants

\section{Data Processing}

Data has been imported into computer and analyzed using SPSS11.0. 


\subsection{Transition from individual-level data to team level data}

In this research, the team other than the individual is the subject for analysis. Thus individuallevel data should be converted into team-level data.

Rwg is used to measure the statistical agreement to which individual members' perceptions converge in assessing aspect their team. If Rwg was more than 0.7 , the variable will be thought to be a team-level variable and means of team member's individual data are used to represent the team's condition (James, L.R., Demaree, R.G., Wolf, G., 1984). Data of 3 teams didn't meet this criterion, these data were excluded out of further statistical analysis.

\subsection{Descriptive statistics}

Calculate mean, SD, and correlation coefficient matrix of self-management teams.( Table 2)

\begin{tabular}{|c|c|c|c|c|c|c|c|c|c|}
\hline & Mean & SD & 1 & 2 & 3 & 4 & 5 & 6 & 7 \\
\hline \multirow{2}{*}{$\begin{array}{l}\text { 1.team } \\
\text { learning }\end{array}$} & 5.7 & 0 & 1.0 & & & & & & \\
\hline & 3 & .40 & 0 & & & & & & \\
\hline \multirow{2}{*}{$\begin{array}{l}2 . \\
\text { normative } \\
\text { motivation }\end{array}$} & 4.8 & 0 & 0.6 & 1.0 & & & & & \\
\hline & 2 & .32 & $7^{* *}$ & 0 & & & & & \\
\hline \multirow{2}{*}{$\begin{array}{l}\text { 3. rational } \\
\text { motivation }\end{array}$} & 6.1 & 0 & 0.7 & 0.5 & 1.0 & & & & \\
\hline & 7 & .32 & $8 * *$ & $4 * *$ & 0 & & & & \\
\hline \multirow{2}{*}{$\begin{array}{l}\text { 4.team } \\
\text { trust }\end{array}$} & 4.0 & 0 & 0.6 & 0.6 & 0.6 & 1.0 & & & \\
\hline & 7 & .31 & $9 * *$ & $6 * *$ & $1 * *$ & 0 & & & \\
\hline \multirow{2}{*}{$\begin{array}{l}\text { 5.team } \\
\text { conflict }\end{array}$} & 2.5 & 0 & - & - & - & - & 1.0 & & \\
\hline & 4 & .51 & $0.25 * *$ & $0.41 * *$ & $0.32 * *$ & $0.33^{* *}$ & 0 & & \\
\hline \multirow{2}{*}{$\begin{array}{l}\text { 6.team } \\
\text { leadership: } \\
\text { democracy }\end{array}$} & 4.7 & 0 & 0.5 & 0.1 & 0.3 & 0.0 & - & 1.0 & \\
\hline & 6 & .55 & $9 * *$ & $4 * *$ & $8^{* *}$ & 8 & 0.05 & 0 & \\
\hline \multirow{2}{*}{$\begin{array}{l}\text { 7.team } \\
\text { leadership: } \\
\text { feasance }\end{array}$} & 6.0 & 0 & 0.6 & 0.2 & 0.5 & 0.5 & - & 0.5 & 1.0 \\
\hline & 1 & .33 & $8 * *$ & $3 * *$ & $1 * *$ & $6 * *$ & 0.03 & $8 * *$ & 0 \\
\hline
\end{tabular}

$*$ means $\mathrm{p}<0.05, * *$ means $\mathrm{p}<0.01$

Table 2. Mean, SD, and correlation coefficient matrix of self-management teams

Calculate mean, SD, and correlation coefficient matrix of superior-direction teams.( Table 3)

\begin{tabular}{|l|l|l|l|l|l|l|l|l|l|}
\hline & Mean & SD & 1 & 2 & 3 & 4 & 5 & 6 & 7 \\
\hline $\begin{array}{l}1 . \text { team } \\
\text { learning }\end{array}$ & 5.9 & 0 & 1.0 & & & & & & \\
\cline { 2 - 10 } & 6 & .36 & 0 & & & & & & \\
\hline $\begin{array}{l}2 . \\
\text { normative } \\
\text { motivation }\end{array}$ & 4.5 & 0 & 0.6 & 1.0 & & & & & \\
\cline { 2 - 10 } & 6 & .36 & $3^{* *}$ & 0 & & & & & \\
\hline
\end{tabular}




\begin{tabular}{|c|c|c|c|c|c|c|c|c|c|}
\hline \multirow{2}{*}{$\begin{array}{l}\text { 3. rational } \\
\text { motivation }\end{array}$} & 5.8 & 0 & 0.6 & 0.6 & 1.0 & & & & \\
\hline & 9 & .27 & $6 * *$ & $5 * *$ & 0 & & & & \\
\hline \multirow{2}{*}{$\begin{array}{l}\text { 4.team } \\
\text { trust }\end{array}$} & 3.9 & 0 & 0.6 & 0.5 & 0.6 & 1.0 & & & \\
\hline & 1 & .30 & $4 * *$ & $0 * *$ & $1 * *$ & 0 & & & \\
\hline \multirow{2}{*}{$\begin{array}{l}\text { 5.team } \\
\text { conflict }\end{array}$} & 2.7 & 0 & - & - & - & - & 1.0 & & \\
\hline & 0 & .39 & $0.35^{* *}$ & $0.40^{* *}$ & $0.40^{* *}$ & $0.48^{* *}$ & 0 & & \\
\hline \multirow{2}{*}{$\begin{array}{l}\text { 6.team } \\
\text { leadership: } \\
\text { democracy }\end{array}$} & 4.4 & 0 & 0.5 & 0.3 & 0.3 & 0.4 & - & 1.0 & \\
\hline & 3.3 & .59 & $7^{* *}$ & $1 * *$ & $0 * *$ & $0 * *$ & $0.26 * *$ & 0 & \\
\hline \multirow{2}{*}{$\begin{array}{l}\text { 7.team } \\
\text { leadership: } \\
\text { feasance }\end{array}$} & 5.6 & 0 & 0.8 & 0.5 & 0.7 & 0.6 & - & 0.4 & 1.0 \\
\hline & 0 & .33 & $3 * *$ & $7 * *$ & $2^{* *}$ & $7 * *$ & $0.34^{* *}$ & $0 * *$ & 0 \\
\hline
\end{tabular}

$*$ means $\mathrm{p}<0.05, * *$ means $\mathrm{p}<0.01$

Table 3 . Descriptive Statistics of Superior-direction teams

\subsection{Common method biases}

Common methed biases is a kind of systematic error due to same source of data. All data of this research came from same participants by questionnaire (Zhou Hao, Long Lirong, 2004). So, common method biases must be tested and be proved not too strong to affect accuracy of result.

Common method biases in this research were examined using statistical remedies (Harman's single factor analysis technique), and the results find that it were acceptable.( $\mathrm{X} 2 / \mathrm{df}=5.97$, $\mathrm{CFI}=0.75, \mathrm{NFI}=0.72, \mathrm{RMSEA}=0.22$ )

\section{Result}

Team motivation, team trust, team leadership are positive predictor of team learning respectively, both in self-mangement team and superior-direction team. Team conflict have negative relationship with team learning in both two type of team. Hypothese 1 and hypothese 2 are comfirmed.

When putting 4 predict variables into regression equation simultanously, different contributions of 4 variables to team learning between two type of teams were presented respectively. (Table 4)

\begin{tabular}{|l|l|l|}
\hline Independent Variables & Self management team & Superior direction team \\
\hline normative motivation: & $0.194 *$ & 0.312 \\
\hline rational motivation: & 0.041 & 0.286 \\
\hline team trust & 0.063 & 0.237 \\
\hline team conflict & 0.044 & 0.073 \\
\hline team leadership: feasance & $0.253^{* *}$ & $0.375^{*}$ \\
\hline team leadership: democracy & $0.555^{* *}$ & 0.130 \\
\hline
\end{tabular}

Table 4. Linear Regression 
Normative motivation, team leadership (including feasance and domocracy) positivly predict team learning significantly in self-management team, whereas team leader's feasance is the only significant predictor which positively predict team learning in superior-direction team. Hypothese 3 is comfirmed.

\section{Conclusion}

Team type as a variable was out of view when scholars discussed influential factors of team learning. Different type of teams may induce diverse team dynamics and different mechanism of team learning. Kozlowski et al. (1999) identified different teams by 2 dimensions: roles and performance demands(Kozlowski S.W.J., et al.,1996). Comparing with superior-direction team, self-management team has unique traits in these 2 dimensions. First, Self-management team owes more autonomy, accordingly have more responsibility. That is to say, self-management team faces higher performance pressures independently, but superiordirection team, owing to accept some instruments from superiors, encounter less performance demands. Second, selfmanagement team shows less segmentation in functions, but superior-direction team tends to divide functions into different individuals. So, formal roles are popular in superior-direction team, but rarely be found in self-management team. Under performance pressure and informal role pattern, self-management team need a strong leadership, leaders must balance performance demands and interpersonal relationship. So, team leadership becomes significant predictor in regression equation. Because of ambiguous functional division, more cooperation and coordination exist in self-management team, and members' normative motivation become more salient. Superior-direction teams have clear team-structure and division of work, and get instructions in magnitude events from higher rank officers. So, if leaders of super-direction team show their democratic leadership, maintain harmonious interpersonal relationship and diminish conflict of team members, team learning occurs.

\section{Corresponding Author}

Zhang wei

Geography Department, Dezhou University, Dezhou, Shandong 253023, China

Email: liuhaodzu@163.com

\section{References}

Edmondson A. C., "Learning from Mistakes Is Easier Said than Done: Group and Organizational Influences on the Detection and Correction of Human Error", Journal of Applied Behavioral Science, Vol. 32, No. 1, pp 5-32. 1996.

Zenon Chaczko, Jenny Quang, Bruce Moulton, "Knowledge Transfer Model for the Development of Software Requirements Analysis CASE Tools to Be Used in Cross Time- Zone Projects", JDCTA: International Journal of Digital Content Technology and its Applications, Vol.4, No. 1, pp. 10 15, 2010. 
Hoever, I. J., et al., "Fostering Team Creativity: Perspective Taking as Key to Unlocking Diversity's Potential," Journal of Applied Psychology, advance online publication, doi:10.1037/a0029159. 2012.

Chan C. C., "A Examining the Effects of Internal and External Team Learning on Team Performance", Team Performance Management, Vol. 9, No. 7, pp174-181, 2003.

Xiao Yuchun, "A Theory and Application Research on Building Learning Team in Model Enterprises", Doctoral Dissertation, East China Normal University, China, 2003.

Cajendran R. S., et al., "Innovation in Globally Distributed Teams: The Role of LMX, Communication Frequency, and Member Influence on Team Decisions", Journal of Applied Psychology, advance online publication, doi: 1037/a0028985. 2012.

Cannon M. A., Edmondson A., "Confronting Failure: Antecedent and Consequence of Shared Learning-Oriented Beliefs in Organizational Work Groups", Annual meeting of the Academy of Management Conference, Toronto, Ontario, Canada, 2000.

Argote L., et al, "Group Learning Curves: The Effects of Turnover and Task Complexity on Group Performance", Journal of Applied Social Psychology, Vol.25, pp. 512-529. 1995.

Wang Xiuli, Liu Dianzhi, Wu Tiejun, Peng Duhong, Li Jun, "The Research on Variables Affecting Effectiveness of Team Learning of Zhangzhou Teacher College Students", International Conference on Control, Automation and System Engineering, 2011.

Weaver J.L., et al., "Motivation in Teams". In M. M. Beyerlein \& D. A. Johnson (Eds.), Advance in Interdisciplinary Studies of Work Team (Vol. 4, pp.167-191).Greenwich, CT: JAI Press.1997.

Stewart G. L., Barrick M.R., "Peer-Based Control in Self-Managing Teams: Linking Rational and Normative Influence With Individual and Group Performance", Journal of Applied Psychology, Advance online publication, doi:10.1037/a0025303,2011.

Edmondson A.C., "Psychological Safe and Learning Behavior in Work Teams", Administrative Science Quarterly, Vol. 44, No.2, pp. 350-383, 1999.

Edmondson A. C., "The Local and Variegated Nature of Learning in Organizations: A Group-Level Perspective", Organization Science, Vol.13, No. 2, pp. 128-146, 2002.

Ruojuan Xue, Wenpeng Lu, Qikun Zhang, "Group Key Agreement Protocol based on Grouping in Ad Hoc Network", AISS: Advances in Information Sciences and Service Sciences, Vol. 3, No.11, pp. $365 \sim 373,2011$. 
Wu Tiejun, Liu Dianzhi, Bi Xin, "Team Learning Orientation and Conflicts Influence Team Performance in Different Task Difficulties", IEEE International Conference on Advance Management Science, pp.183-186, 2010.

Jehn K.A., "Enhancing Effectiveness: An Investigation of Advantages and Disadvantages of Value-Based Intragroup Conflict", International Journal of Conflict Manage. Vol. 5, pp.223-238, 1994.

Jehn K.A., "Multimethod Examination of Detriment of Intragroup Conflict". Administrative Science Quarterly, Vol. 40, pp. 256-282, 1995.

Jehn K.A., Northcraft G.B., Neale M.A., "Why Differences Make a Difference: A Field Study of Diversity, Conflict, and Performance in Work Groups". Administrative Science Quarterly, Vol.44, No.4, pp. 741-763, 1999.

De Dreu CKW., Weingart L.R., "Task versus Relationship Conflict, Team Performance, and Team Member Satisfaction: A Meta-Analysis",Journal of Applied Psychology. Vol.88, pp.741-749,2003.

Ilgen D.R, Hollenbeck J.R, Johnson M., Jundt D., "Teams in Organization: From InputProcess-Output Models to IMOI models", Annual Review of Psychology, Vol. 56, pp. 517543, 2005.

James, L.R., Demaree, R.G., Wolf, G., "Estimating with-in-group Inter Rater Reliability with and without Response Bias", Journal of Applied Psychology, Vol. 6, No.1, pp. 85-98, 1984.

Zhou Hao, Long Lirong, "Statistical Remedies for Common Method Biases", Advances in Psychological Science, Vol.12, No.6, pp. 942-950, 2004.

Kozlowski S.W.J., et al., "A Dynamic Theory of Leadership and Team Effectiveness: Developmental and Task Contingent Leader Roles". In G. R. Ferris (Ed.), Research in personnel and human resource management (Vol. 14, p 253-305). Greenwich CT: JAI Press, 1996. 